\title{
ЯМААН АРЦ (JUNIPERUS SIBIRICA BURGSD.)-НЫ МУТАГЕНИЙ ҮЙЛЧЛЭЛИЙГ ДАРАНГУЙЛАХ ИДЭВХИЙН СУДАЛГАА
}

\author{
Д.Бямбасух $x^{l}$, Г.Одонтуяа ${ }^{2}$, Ж.Батх $Y^{l}$ \\ ${ }^{\prime}$ МУИС-ийн Биологийн факультет, Биохими-Биоорганик химийн тэнхим, иахим шуудан: batkhuи@biology.nuт.edu.mn \\ ${ }^{2}$ ШУА, Хими-Химитехнологийн хүрээлэн, Байгалийн нэгдлийн химийн лаборатори, иахим шуудан: odnoo_4091@yahoo.com
}

\section{Оршил}

Орчин үед амьд организмын удамшлын материалыг гэмтээж мутаци үүсгэдэг хими, физик, биологийн олон хүчин зүйлийг илрүүлээд байна. Нийлэг болон байгалийн гаралтай мутагенүүд нь хүний зарим өвчлөл, ялангуяа хорт хавдар үүсэх үндэс болдог ([1]-д). Бэлгийн эсийн ДНХ-ийн гэмтлүүд нь удамшлын өвчний шалтгаан болж үр зулбалт, хэвийн бус ураг бий болох нөхцлийг бүрдүүлдэг бол биеийн эсийн ДНХ-ийн гэмтэл нь хорт хавдар үүсэх шалтгаан болдог ([2,3]-д). Иймээс хүрээлэн буй орчин болон хүнсний бүтээгдэхүүний генотоксикологийн шинж чанарыг судлахаас гадна байгалийн янз бүрийн түүхий эдээс энэхүү хорт хавдар ба удамшлын өвчинийг үүсгэдэг мутагений үйлчлэлийн эсрэг идэвхтэй нэгдлийг хайж олох нь мутаци үүсгэгч хүчин зүйлсээс урьдчилан сэргийлэх, цаашлаад хүний геномын аюулгүй байдлыг хангахад чухал ач холбогдолтой юм.

Сүүлийн жилүүдэд манай оронд хорт хавдраар өвчлөгсдийн тоо өссөөр байна. Хавдар судлалын үндэсний төвөөс гаргасан судалгаагаар 2008 онд 4267 хорт хавдрын шинэ тохиолдол бүртгэгдсэнээс хоол боловсруулах эрхтэн тогтолцооны хорт хавдар $74 \%$-ийг эзэлж байна ([4]-д). Энэ нь хүрээлэн буй орчны бохирдол болон баталгаагүй хүнсний бүтээгдэхүүн хэрэглэж байгаатай холбоотой хэмээн үзэх үндэслэлтэй юм.

Байгалийн гаралтай эмт бодис, эмийн түүхий эдээс мутагений үйлчлэлийг саатуулах идэвхтэй нэгдлүүдийг шинээр илрүүлэх чиглэлийн судалгаа дэлхий дахинд эрчимтэй хийгдэж байна.

Иймээс бид энэхүү судалгаандаа Монгол орны уламжлалт анагаах ухаанд янз бүрийн өвчнийг анагаахад хэрэглэж ирсэн зарим эмийн ургамлын ([5]-д) мутагений үйлчлэлийг дарангуйлах идэвхийг тодорхойлох, улмаар эдгээр ургамлаас өндөр идэвх үзүүлсэн Juniperus sibirica Burgsd. (Ямаан ари)-ийг сонгон, түүнээс мутагений үйлчлэлийг дарангуйлах идэвхтэй бодисыг илрүүлж, цэврээр ялгаж, молекулын бүтэц байгууламжийг нь тогтоох зорилго тавьсан болно. 


\section{Судалгааны материал, арга зүй}

\section{Ургамлаа хандлах, цэвэр бодис ялгасан зүй}

Судалгааны дээж ургамлуудыг Монгол орны хангай, говь, хээрийн бүслүүрээс 2004-2008 онд түүж, сүүдэр сэрүүн газар хатааж бэлтгэв. Тэдгээрийн ургамлын ангилал зүйн тодорхойлолтыг Шинжлэх Ухааны Академийн, Ботаникийн Хүрээлэнгийн эрдэм шинжилгээний ахлах ажилтан, профессор Ч.Санчир тодорхойлов.

Ямаан арцны агаарын хуурай газрын дээд хэсгээс 282 гр-г авч, метанолоор 5 удаа тасалгааны температурт хандалж, хандыг $40-45^{\circ} \mathrm{C}-$ д вакуум ууршуулагчаар ууршуулж, 77 гр өтгөн ханд гарган авсан. Дээр нь түүнтэй тэнцүҮ хэмжээний нэрсэн ус нэмж сайтар хутгаж уусгана. Усанд уусаагүй үлдсэн хэсэг (53 гр)-ийг силикагель адсорбенттай (400 гр) баганан хроматографиар $\mathrm{CHCI}_{3}$; $\mathrm{CHCI}_{3}: \mathrm{MeOH}$ - 95:5; 90:10; 80:20 уусгагчийн системээр элюацалж нийт 75 фракц авсныг 29 фракц (F1-29) болгон нэгтгэв. Мутагений үйлчлэлийг дарангуйлах идэвх бүхий нэгдлийг F1 ба F3-с тус тус ялгалаа.

F1-г (700 мг) силикагель адсорбенттай (21 гр) баганан хроматографиар н- $\mathrm{C}_{6} \mathrm{H}_{14}: \mathrm{CHCI}_{3}$ уусгагчийн системээр элюацалж нийт 281 фракц авсныг 25 фракц (F1-1-25) болгон нэгтгэв. Эдгээрийн F1-2 (230 мг)-с 1-р бодис (JS1) 50 мг, F1-19 (230 мг)-с 2-р бодисыг (JS2) 8 мг тус тус бэлдмэлийн нимгэн үеийн хроматографын (HYX) аргаар гексан ба гексан:хлороформ -60:40 уусгагчийн системд ялгасан болно.

3-рбодисыг(JS3,22мг)F3(110мг)-сметанолоорталстжууланцэвэрбайдлаарялганавлаа.

\section{Ургамлаас эфирийн тос ялгасан арга зуй}

Ямаан арцны газрын дээд хэсгээс 70 гр-ыг авч 5-6см хэмжээтэй жижиглээд Адамсын типийн Клевенжерийн аппаратанд хийж 3 цагийн турш усны уураар нэрнэ. Ингэхэд дээжнээс эфирийн тос усны ууртай хамт нэрэгдэн гарч ирнэ. 70 гр газрын дээд хэсгээс 1.2 мл цагаан шар өнгөтэй эфирийн тос гарган авав.

\section{Тест бичил биетэн, урвалэс бодис}

Тест бичил биетнээр амин хүчил гистидинийг нийлэгжүүлэх чадваргүй ауксотроф омог болох Salmonella typhimurium TA1537 (his, uvrB, rfa, bio-, frameshift mutation)-г хэрэглэв.

Стандарт мутаген болох 9-аминоакридин (Wako, Japan), 10xVBE глюкоз агар, тэжээлийн aгap (HIMEDIA, India), л-гистидин, (+)-биотин (Wako, Japan), ДМСО(диметилсульфоксид) (Sigma, Japan)-г туршилтанд ашиглав. Метанол, хлороформ, этилацетат (Union lab, China), метанол (Dae Jung, Korea), хлороформ (Реактив, ОХУ), гексан (Экос-1, ОХУ), силуфол $60 \mathrm{~F}_{254}$ (MERCK, Germany), силикагель Wakogel C-200 (Wako, Japan) тус тус хэрэглэв. 
Мутагений үйлчлэлийг дарангуйлах идэвхийг тодорхойлох арга зүй

Ургамлын хандны мутагений үйлчлэлийг дарангуйлах идэвхийг Эймсийн сорилоор (Ames test) [6] тодорхойллоо. 0.5 мл фосфатын буфер (0.1M, pH=7.0), 0.1 мл ургамлын ханд (1 мг/мл), 0.1 мл бактерийн урьдчилсан өсгөвөр (1.2х107 эс/мл), 0.1 мл мутаген (0.2 мг/мл) - ийг сайтар хольж, $37^{\circ} \mathrm{C}$-д 30 минут өсгөвөрлөсний дараа түүнээс 0.1 мл-ийг авч 3 мл хагас шингэн тэжээлийн орчинд хийж сэгсэрнэ. Түүнийг Вогел-Боннерийн хатуу тэжээлийн орчин савласан Петрийн аяганд тархаан, $37^{\circ} \mathrm{C}$-д 48 цаг өсгөвөрлөсний дараа эргэх мутацид орсон колонийг (revertant) тоолно.

Ургамлын хандны мутагений үйлчлэлийг саатуулах идэвхийг дараах томъёогоор тооцоолно.

Мутагений үйлчлэлийг саатуулсан идэвхи $\quad(\%)=\frac{\mathrm{a}-\mathrm{b}}{\mathrm{a}-\mathrm{c}} \times 100 \quad$ [1]

a- $\quad$ Эерэг хяналт (мутагентэй аяган дах колоний тоо)

b- $\quad$ Туршилт (мутаген, ургамлын хандтай аяган дах колоний тоо)

c- Сөрөг хяналт (мутаген, ургамлын хандгүй аяган дах колоний тоо)

Ургамлын хандны мутагенийг дарангуйлах идэвхийг эерэг хяналтын аяган дахь колоний тоотой харьцуулж, хувиар илэрхийлэв.

Ургамлын ханд мутагений үйлчлэлийг 25\% хүртэл дарангуйлж байвал ерөнхийдөө идэвхигүй, 25-40\% хүртэл саатуулбал дунд зэргийн идэвхитэй, 40-өөс дээш хувиар дарангуйлж байвал мутагений үйлчлэлийг хүчтэй дарангуйлж байна гэж үздэг ([7]-д).

Статистик анализ: Хэмжилт тус бүрийг 3 давталттайгаар гүйцэтгэсэн ба үр дүнд утга \pm стандарт хазайлт (SD) - ыг оруулав.

\section{Бодисын молекулын бүтэц байгууламжсийг тогтоосон арга зүй}

Цэвэр нэгдлийн (JS3) молекулын бүтэц байгууламжийг нэг хэмжээст цөмийн соронзон резонансын (ЦСР) спектроскопын аргаар тогтоов. Бодисыг дейтерийн $\mathrm{CDCI}_{3}$-Д уусгаж ${ }^{1} \mathrm{H}$ ба ${ }^{13} \mathrm{C}$ ЦСР спектрийг 270 ба 67 МГц-д JEOL JNM-EX270 FT-NMR спектрометрт триметилсилан буюу дотоод стандарттай харьцуулан бүртгэсэн болно.

\section{Судалгааны үр дүн, дүгнэлт, хэлцэмж}

Бид энэхүү судалгаагаар нийтдэ 10 зүйл ургамлын метанолын 20 хандны мутагений үйлчлэлийг дарангуйлах идэвхийг тодорхойлсон ба үр дүнг хүснэгт 1-д үзүүллээ. 
ХУснэгт 1. Ургамльн метанолон ханднь мутагений үйлчлэлийг дарангуйлах идэвх

\begin{tabular}{|c|c|c|c|c|}
\hline \multirow{2}{*}{ Ургамлын нэрс } & \multirow{2}{*}{ Эрхтэн } & \multicolumn{2}{|c|}{$\begin{array}{c}\text { Петрийн аяган дах } \\
\text { колоний тоо }\end{array}$} & \multirow{2}{*}{$\begin{array}{c}\text { Мутагений } \\
\text { үйлчлэлийг } \\
\text { дарангуйлал, \% }\end{array}$} \\
\hline & & $\begin{array}{c}\text { Эерэг } \\
\text { хяналт }^{*}\end{array}$ & Туршилт $^{* *}$ & \\
\hline $\begin{array}{l}\text { Achnatherum splendens } \\
\text { (Trin) }\end{array}$ & газрын дээд хэсэг & $197 \pm 4.2$ & $103 \pm 2.8$ & 49.7 \\
\hline \multirow{3}{*}{ Axyris prostrata $L$. } & навч & $73 \pm 1.4$ & $60.5 \pm 6.3$ & 19 \\
\hline & иш & $73 \pm 1.4$ & $50.5 \pm 7.6$ & 34 \\
\hline & үндэс & $125 \pm 2.1$ & $136 \pm 8.4$ & - \\
\hline \multirow{2}{*}{ Carum buriaticum Turcz. } & цэцэг+навч & $236 \pm 2.1$ & $149 \pm 7$ & 39.5 \\
\hline & иш & $236 \pm 2.1$ & $174 \pm 2.8$ & 28.33 \\
\hline \multirow{2}{*}{$\begin{array}{l}\text { Cynoglossum divaricatum } \\
\text { Steph. }\end{array}$} & Yp & $74.5 \pm 4.9$ & $48 \pm 5.6$ & 41.5 \\
\hline & иш & $74.5 \pm 4.9$ & $35 \pm 4.2$ & 61.5 \\
\hline \multirow{2}{*}{ Galeopsis bifida Boenn. } & цэцэг+навч & $165 \pm 1.4$ & $147 \pm 7$ & 11.5 \\
\hline & иш & $165 \pm 1.4$ & $134 \pm 1.4$ & 20.1 \\
\hline Dasiphora fruticosa (L.) & газрын дээд хэсэг & $165 \pm 1.4$ & $170 \pm 1.4$ & - \\
\hline \multirow{2}{*}{ Juniperus sibirica Burgsd. } & навч & $147 \pm 4.9$ & $98.5 \pm 6.3$ & 40 \\
\hline & иш & $147 \pm 4.9$ & $92 \pm 2.6$ & 43 \\
\hline \multirow{2}{*}{$\begin{array}{l}\text { Lespedeza dahurica (Laxm) } \\
\text { Schipdl. }\end{array}$} & цЭЦЭГ & $159 \pm 1.4$ & $134 \pm 2.1$ & 15 \\
\hline & навч & $159 \pm 1.4$ & $137 \pm 2.1$ & 15 \\
\hline \multirow{2}{*}{ Patrina rupestris (Pall.) } & навч & $165 \pm 1.4$ & $147 \pm 2.1$ & 11.5 \\
\hline & иш+үндэс & $165 \pm 1.4$ & $150 \pm 1.4$ & 9.6 \\
\hline \multirow{3}{*}{ Sisymbrium Loeselii L. } & цЭцЭГ & $152.3 \pm 13.3$ & $158.5 \pm 0.7$ & - \\
\hline & навч & $152.3 \pm 13.3$ & $166 \pm 2.8$ & - \\
\hline & иш & $152.3 \pm 13.3$ & $148.5 \pm 9.1$ & 9.6 \\
\hline
\end{tabular}

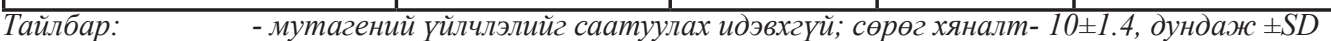

* Мутагений конценттраи (2.5мкг/аяга)

** Ургамлын метанолон хандны концентрац (12.5мкг/аяга)

Судалгааны дүнд Achnatherum splendens Trin.-ийн газрын дээд хэсэг 49.7\%, Cynoglossum divaricatum Steph.-ийн үр 41.5\%, иш 61.5\%, Carum buriaticum Turcz.-ийн цэцэг+навч 39\%, Juniperus sibirica Burgsd.-ийн навч, иш 40\% ба 43\%-иар тус тус стандарт мутаген 9-аминоакридиний үйлчлэлийг хамгийн ихээр дарангуйлж байна. Харин Lespedeza dahurica (Laxm) Schipdl.-ийн цэцэг, навч тус бүр 15\%-иар, Patrinia rupestris Pall.-ийн навч 11.5\%, иш+үндэс 9.6\%-иар мутагений үйлчлэлийг сул дарангуйлсан бол Sisymbrium Loeselii L.ийн цэцэг, навч, Dasiphora fruticosa L.-ийн газрын дээд хэсэг, Axyris prostrata L.-ийн үндэс нь мутагенийг дарангуйлах идэвхгүй байлаа.

Бид цаашдын судалгаанд Juniperus sibirica Burgsd.-ийг сонгон авч, түүний газрын дээд хэсгээс (282 гр) бэлтгэсэн метанолон хандны усанд ууссан ба үл ууссан хэсгүүдийн мутагений үйлчлэлийг дарангуйлах идэвхийг тогтоож улмаар усанд уусаагүй хэсгээс идэвхтэй үйлдэлтэй нэгдлийг ялгах, молекулын бүтэц байгууламжийг тогтоох судалгааг хийсэн дүнг бүдүүвч 1.-д нэгтгэн үзүүллээ. 
БүдҮҮвч 1. Juniperus sibirica Burgsd.-с мутагений үйлчлэлийг дарангуйлах идэвхтэй бодисын ялгалт ба идэвх

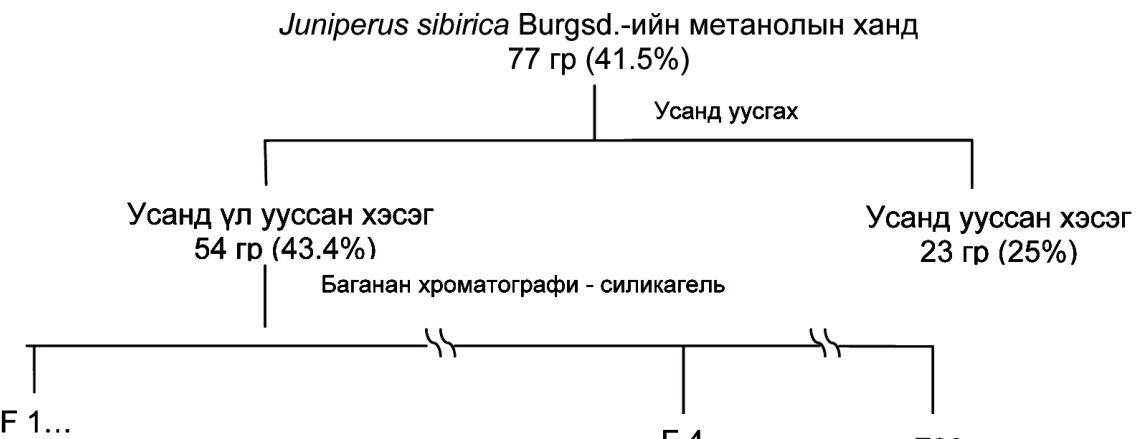

700 мг $(60.9 \%)$

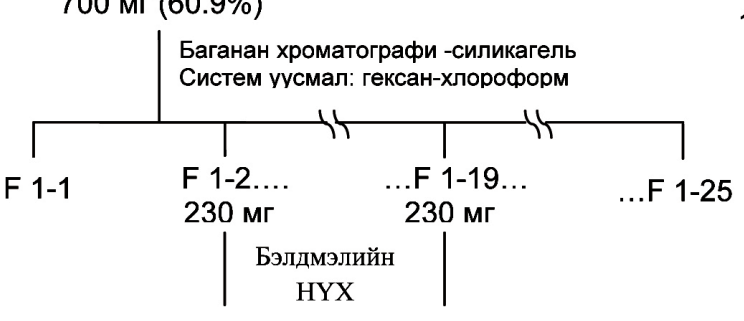

$\mathrm{F} 4 \ldots$ 110 мг (56\%)

... F29
Метанолоос

талстжуулах

\section{JS-1 \\ $50 \mathrm{Mr}(75 \%)$ \\ JS-2 \\ 8 мг (37\%)}

\section{$22 \mathrm{Mr}(55 \%)$}

Тайлбар: () - хаалтанд тухайн фраки ба иэвэр нэгдлийн стандарт мутагений үйлчлэлийг дарангуйлах идэвхийг хувиар илэрхийлэв.

Хроматографын ялгалтын үе шат бүрд мутагений үйлчлэлийг дарангуйлах идэвхийг шалгаж, идэвхтэй фракцыг хроматографын аргаар ялгаж, 3 бодисыг (JS-1, JS-2, JS-3) цэврээр ялгасан ба тэдгээрийн мутагений үйлчлэлийг дарангуйлах идэвх ба мутаци үүсгэх идэвхийг шалгалаа. Учир нь цэвэр нэгдлүүд нь өөрсдөө мутаген буюу мутаци үүсгэх идэвхтэй байх боломжтой юм (Хүснэгт 2 ба 3).

Хүснэгт 2. Цэвэр бодисуудын мутагений үйлчлэлийг дарангуйлах идэвхийн үр дүн

\begin{tabular}{|c|c|c|c|c|c|}
\hline \multirow[b]{2}{*}{ Бодисын нэр } & \multirow{2}{*}{$\begin{array}{c}\text { Концентрац } \\
\text { (мг/мл) }\end{array}$} & \multicolumn{3}{|c|}{ Петрийн аяганд ургасан колоний тоо } & \multirow[b]{2}{*}{$\begin{array}{c}\text { Дарангуйлах } \\
\text { хувь (\%) }\end{array}$} \\
\hline & & $\begin{array}{c}\text { Эерэг } \\
\text { хяналт* }\end{array}$ & Туршилт & $\begin{array}{l}\text { Сөрөг } \\
\text { хяналт }\end{array}$ & \\
\hline JS-1 & 0.5 & $205.5 \pm 20.5$ & $29 \pm 2.82$ & $11.5 \pm 2.12$ & 75 \\
\hline JS-2 & 1 & $120 \pm 2.82$ & $78.5 \pm 0.7$ & $8.5 \pm 3.53$ & 37 \\
\hline JS-3 & 1 & $320 \pm 14.1$ & $155 \pm 7.07$ & $21 \pm 1.41$ & 55 \\
\hline
\end{tabular}

Тайлбар: дундаж $\pm S D ;{ }^{*}$ Мутагений концентраи (2.5мкг/аяга) 
Хүснэгт 3. Цэвэр бодисуудын мутаии Үүсгэх идэвх

\begin{tabular}{c|cc|c|c|c}
\hline \multirow{2}{*}{ Бодисын нэр } & \multirow{2}{*}{$\begin{array}{c}\text { Концентрац } \\
\text { (мг/мл) }\end{array}$} & \multicolumn{2}{c}{ Петрийн аяганд ургасан колоний тоо } & \multicolumn{1}{c}{ Мутаци үүсгэх } \\
\cline { 3 - 5 } & & Хяналт* & Туршилт & $\begin{array}{c}\text { Сөрөг } \\
\text { хяналт** }\end{array}$ & $\begin{array}{c}\text { хувь (\%) } \\
\text { JS-1 }\end{array}$ \\
\cline { 3 - 5 } JS-2 & 0.5 & $123 \pm 12$ & $7 \pm 2.8$ & $9.5 \pm 4.9$ & - \\
JS-3 & 1 & $123 \pm 12$ & $12.5 \pm 2.1$ & $9.5 \pm 4.9$ & - \\
\hline
\end{tabular}

Тайлбар: * Хяналт- 9-аминоакридин; ** Сөрөг хяналт- уусгагч

Судалгааны дүнд цэвэр бодисууд болох JS-1, JS-2, JS-3 нь тус бүр стандарт мутаген 9-аминоакридиний үйлчлэлийг 75, 37, 55\%-иар тус тус дарангуйлсан ба стандарт бодистой адилаар генд нөлөөлж мутаци үүсгэх идэвхгүй байлаа. Иймд эдгээр бодис десмутаген үйлчлэлийг 9-аминоакридинд үзүүлж байна гэж таамаглаж болох юм.

Мутагений үйлчлэлийг дарангуйлах идэвхтэй бодисуудын молекулын бүтэц байгууламжийг тодорхойлох нь чухал юм.

JS-3 бодис нь цагаан өнгөтэй, талст, хлороформд сайн уусдаг, туйл багатай нэгдэл. HYX-н гексан:этилацетат - 80:20 уусгагчийн системд шалгахад үзэгдэх гэрэлд өнгөгүй, харин хэт ягаан туяаны гэрэлд бүдэг бараан өнгөтэй, 5\% $\mathrm{H}_{2} \mathrm{SO}_{4}$ урвалжаар үйлчлүүлэхэд бас өнгөгүй. Энэ нь тухайн нэгдэлд давхар холбоо, ароматик цагираг байхгүйг илтгэж байна.

Энэхүү нэгдлийн молекулын бүтэц байгууламжийг тогтоохын тулд түүний ${ }^{1} \mathrm{H}$ ба ${ }^{13} \mathrm{C}$ ЦСР спектрийг бүртгэж тайлал хийлээ (Зураг 1 ба 2).

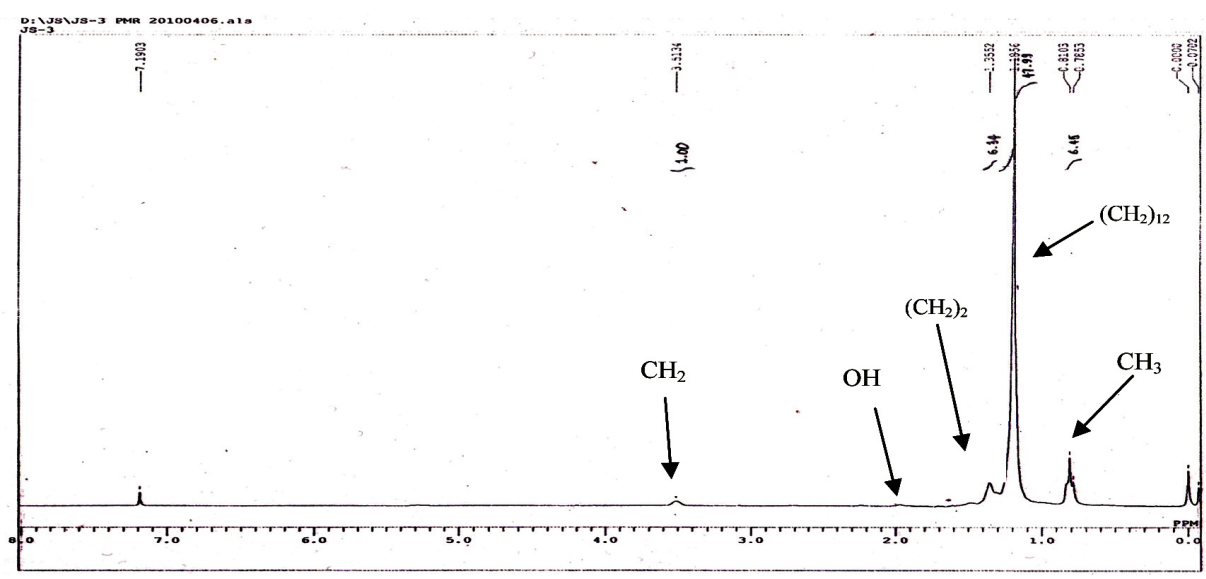

Зураг 1. JS-3 бодисын ${ }^{1}$ Н ЦСР-н спектр

JS-3-н протоны соронзон резонансын спектрийн 0.78-0.81 саяны хэсгийн (с.х.) мужид 3 протоны идэвхтэй - $\mathrm{CH}_{3}$ бүлгийн триплет, 1.18 с.х.-т 24 протоны идэвхтэй $-\mathrm{CH}_{2}$ бүлгийн синглет, 1.35 с.х.-т 3-4 протоны идэвхтэй - $\mathrm{CH}_{2}$ бүлгийн өргөн синглет, 3.51 с.х.-т гидроксил бүлэгтэй холбоотой $-\mathrm{CH}_{2}$ бүлгийн өргөн синглет тус тус илэрснээс түүнийг нэг атомт дээд спирт байж магадгүй гэж таамаглал дэвшүүлсэн. 


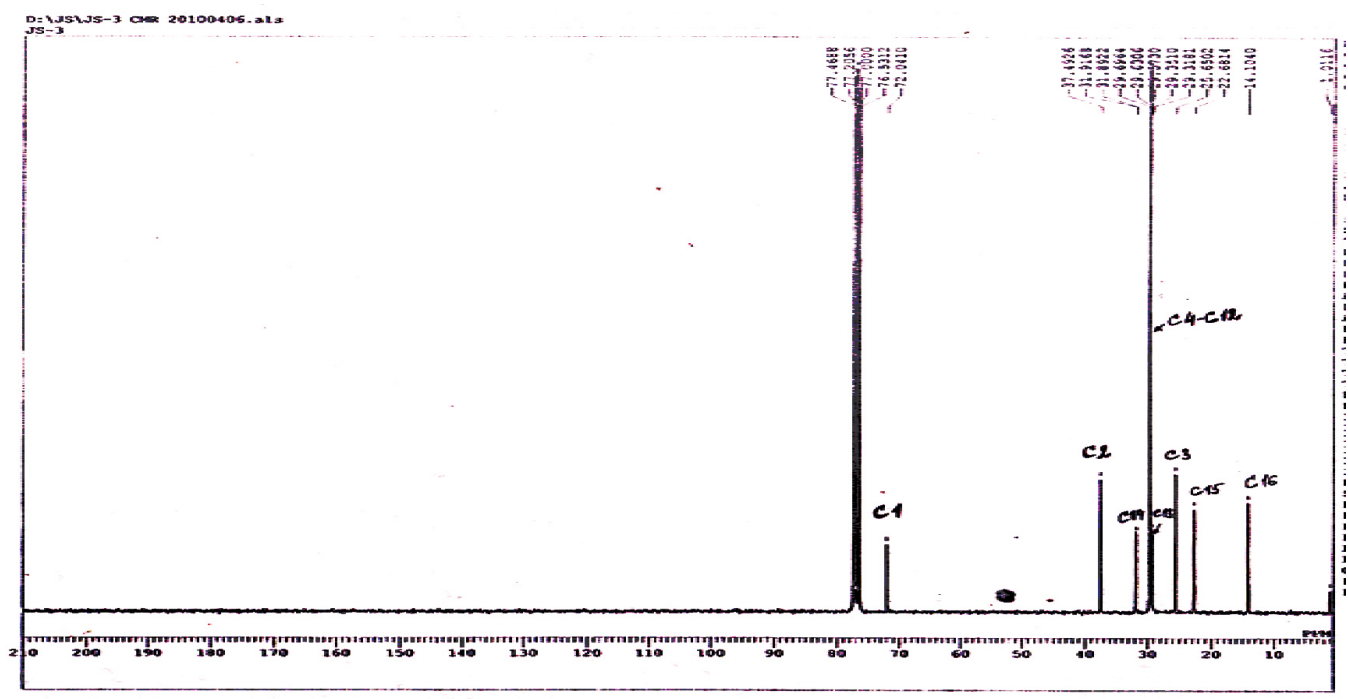

Зураг 2. ЈS-3 бодисын ${ }^{13}$ С ЦСР-н спектр

JS-3 бодисын нүүрстөрөгчийн соронзон резонансын спектрийн 14.1-72.0с.х.-н соронзон орны хүчтэй мужид 8 дохио илэрснээс энэхүү нэгдлийг алифатик нүүрсустөрөгчийн үндсэн хэлхээтэй нэгдэл болохыг илэрхийллээ. Иймд 72.0 c.х.-т C-1 буюу $-\mathrm{CH}_{2} \mathrm{OH}, 37.49$ c.х.-т C-2, 31.9 c.X.-т C-14, 29.31c.х.-т C-13, 25.65 c.х.-т C-3, 22.68 c.х.-т C-15, 14.1 c.х.-т C-16 буюу $-\mathrm{CH}_{3}, 29.65$ с.х.-т C-4 - C-12 байна гэж тайлал хийсэн болно.

JS-3 нэгдлийн ${ }^{1} \mathrm{H}$ ба ${ }^{13} \mathrm{C}$ ЦСР-н спектроскопын шинжилгээ ба түүний физик, хими шинж чанарын үр дүнд молекулын бүтэц байгууламжийг нь 16 нүүрстөрөгчийн атомтай нэг атомт спирт буюу цетилийн спирт гэж таньж тодорхойллоо (Зураг 3).<smiles>CCCCCCC=CCCCCCCCCC(C)O</smiles>

Зураг 3. Цетилийн спирт буюу гексадеканол-1

Цетилийн спиртийг анх халимны тосноос ялгасан байдаг бөгөөд гоо сайхны бүтээгдэхүүний үйлдвэрлэлд хэрэглэдэг байна. Цетилийн спирт болон дээд спиртүүдийн антимутаген үйлчлэлтэй талаар тодорхой мэдээлэл хомс байгаа ба Ямаан арцнаас цетилийн спиртийг ялгаж, түүний молекулын бүтэц байгууламж, мутагений үйлчлэлийг дарангуйлах идэвхийг анх удаа тодорхойлж байгаа нь энэ болно.

Бид мөн Ямаан арины эфирийн тосны мутагений үйлчлэлийг дарангуйлах ба эсийг үхүүлэх идэвхийг шалгасан ба туршилтын үр дүнг хүснэгт 4.-т үзүүлэв. 
Хүснэгт 4. Ямаан арины эфирийн тосны антимутаген ба эсийг үхүҮлэх идэвх

\begin{tabular}{|c|c|c|c|c|c|c|c|c|}
\hline \multirow[b]{2}{*}{ Нэр } & \multirow{2}{*}{ 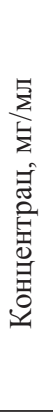 } & \multicolumn{2}{|c|}{$\begin{array}{c}\text { Ургасан колоний } \\
\text { тоо }\end{array}$} & \multirow{2}{*}{ 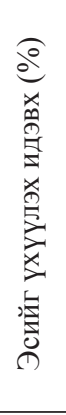 } & \multicolumn{3}{|c|}{ Ургасан колоний тоо } & \multirow{2}{*}{ 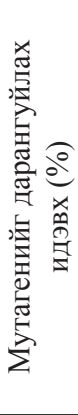 } \\
\hline & & 点 & 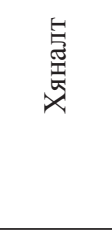 & & 廪 & 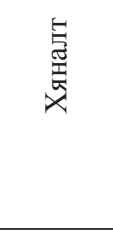 & 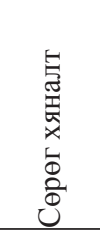 & \\
\hline \multirow{3}{*}{$\begin{array}{c}\text { Эфирийн } \\
\text { тос }\end{array}$} & 10 & - & - & 100 & - & - & - & - \\
\hline & 1 & $8 \pm 5$ & $553 \pm 23$ & 98 & - & - & - & - \\
\hline & 0.1 & $551 \pm 20$ & $553 \pm 23$ & - & $179.5 \pm 3.5$ & $181 \pm 21$ & $11 \pm 5.6$ & - \\
\hline
\end{tabular}

Ургамлаас гарган авсан эфирийн тос нь бактерийн эсрэг, микробын эсрэг, мөөгөнцрийн эсрэг маш өндөр идэвхтэй байдаг ([7, 8]-д). Судалгааны дүнд Ямаан арины эфирийн тос нь Salmonella typhimurium-ийн эсийг үхүүлэх өндөр идэвхтэй байгаа нь бусад өвчин үүсгэгч бичил биетэн, мөөгөнцрийн эсрэг идэвхтэй байх боломжтойг харуулж байна. Иймд Ямаан арияны эфирийн тосны бактерийн эсрэг идэвхийн судалгааг хийх нь зүйтэй юм.

Ургамлын мутагений үйлчлэлийг дарангуйлах идэвхийн судалгаа манай оронд өргөн хүрээтэй хийгдээгүй боловч бидний судалгаагаар идэвхтэй ургамлууд илэрсээр байгаа нь цаашдын судалгааг нарийвчлан хийх шаардлагатайг харуулж байна. Харин гадаад орнуудад энэ чиглэлийн судалгаа эрчимтэй хийгдэж байна. Тухайлбал: Бразилийн Rubem Cesar Horn, Vera Maria Ferro Vargas нарын эрдэмтэд флавоноид, алкалоид, таннинаар баялаг цайны ургамал Maytenus ilicifolia-ийн ханд нь стандарт мутаген 2-аминоантрацений идэвхийг S.typhimurium ТА98 омог дээр 56.71-88.20\%, ТА100 омог дээр 53.98-93.88\%-иар тус тус саатуулж байгааг тогтоожээ ([9]-д).

Мөн Хятадад Anjana Bhatia, Saroj Arora нар Hippophae rhamnoides Linn-н стандарт мутаген болох 2-аминофлуорений үйлчлэлийг саатуулах идэвхийг ТА98, ТА100 омгууд дээр судалж 56.25 \% ба 49.63 \% тус тус дарангуйлж байгааг тогтоосон ([10]-д) ба түүнд агуулагдах флавоноид, витамин, зарим каротиноид зэрэг нэгдлүүд дээрх идэвхийг үзүүлсэн гэж дүгнэжээ.

Хятад, Тайваньд хүнсэнд өргөн хэрэглэгдлэг Хятад луувангийн гексан, хлороформын ханд нь шууд болон шууд бус замаар мутагений идэвхийг дарангуйлж буй нь тогтоогдсон ба эдгээр фракц дахь туйлгүй нэгдлүүд нь акриламид, натрийн азид зэрэг мутагенийг дарангуйлах идэвхтэй байна ([11]-д).

Италид хийгдсэн судалгаагаар Lavandula angustifolia(Лаванд)-ын эфирийн тосны антимутаген идэвхийг Эймсийн сорилоор ТА98 омог дээр шалгахад шууд үйлчлэлтэй мутаген 2-нитрофторын үйлчлэлийг хүчтэй дарангуйлж байсан бөгөөд концентрацаасаа 
шууд хамааралтай үр дүнг үзүүлсэн байна. Мөн эфирийн тос нь Salmonella typhimurium ТА98, ТА100 омгууд дээр мутаци үүсгэхгүй байсан ([7]-д).

Сербид хийгдсэн судалгаагаар Ocimum basilicum L.-ээс гарган авсан эфирийн тос, линалоол, $\beta$-мирцен, 1.8-цинеол нь S.typhimurium TA100 систем дээр UV өдөөх мутацийг 64-77\%-иар хүчтэй саатуулж байсан бол шууд үйлчлэлтэй мутаген 4-нитрохинолин-Nоксидийг 52-67\%-иар хүчтэй саатуулж байсан. Харин эфирийн тосны бүрэлдхүүн 1.8цинеол нь шууд бус үйлчлэлтэй мутаген 2-нитропропаныг сул саатуулж байгааг тогтоосон байна ([8]-д).

Өнөөг хүртэл мутагений эсрэг үйлчлэлтэй олон анги нэгдлийг ургамлаас илрүүлсэн ч тэдгээрийн үйлчлэлийн механизмыг тогтоож чадаагүй байгаа юм.

Бид цаашид JS1, JS2 нэгдлүүдийн молекулын бүтэц байгууламжийг тогтоох, мутагений үйлчлэлийг дарангуйлах идэвхтэй бусад нэгдлийг нэмж цэврээр нь ялгах, тэдгээрийн үйлчлэх механизмыг нь судлах, эмнэлгийн болон урьдчилан сэргийлэх зорилгоор практикт нэвтрүүлэх боломжийг судлах зорилготой байна.

\section{Талархал}

Энэхүу судалгааг хийхэд зөвлөлгөө өгч, S.typhimurium ТА1537 омог болон зарим урвалж бодисоор хангаж, туршилт хийх бололцоог олгосон Японы Тохо Их Сургуулийн Эм Зүйн Факультетийн профессор Fumio Kato, ЦСР-ын спектроскопын хэмжилт хийх боломж олгосон Японы Тохокугийн Эмзүйн Их Сургуулийн профессор Fumihiko Yoshizaki нарт гүн талархлаа илэрхийлье. Мөн уг судалгааны зарим хэсэг Японы Хонда Сан (Honda Foundation)-гаас санхүүжсэн болно. 


\section{Ном зүй}

1. Farrukh A., Maryam Z., Iqbal A. Antimutagenic activity of methanolic extracts of four ayurvedic medicinal plants, Indian J Exp Biol, 2008 Sep; 46(9):668-72.

2. Hope Smith, Tate P.L.. et al. Antimutagenic Activity of Berry Extracts. Journal of Medicinal Food. Winter 2004, 7(4):450-455.

3. Khader M., Bresgen N., Eckl PM. Antimutagenic effects of ethanolic extracts from selected Palestinian medicinal plants. J Ethnopharmacol. 2010 Feb; 3;127(2):319-2.

4. Хавдар Судлалын Үндэсний Төв, Эрдэм Шинжилгээ Сургалт Мэдээллийн Төвөөс гаргасан мэдээ, Өдрийн сонин. №027 (3417) 2010.02.03 8-р нүүр.

5. Лигаа У. Монголын уламжлалт эмнэлэгт эмийн ургамлыг хэрэглэх арга ба жор. УБ. 2006, хуудас 58-59, 64, 99-100, 138-139, 309, 433-434, 488.

6. Maron D.M., Ames B.N. Revised methods for the Salmonella mutagenicity test. Mutat Res. 1983 May;113(3-4):173-215.

7. Evandri M.G, Battinelli L. et al. The antimutagenic activity of Lavandula angustifolia (lavender) essential oil in the bacterial reverse mutation assay. Food and Chemical Toxicology. 2005, 43, 1381-1387.

8. Stajkovic O., Beric-Bjedov T., Mitic-Culafic D., Stancovic S., Vukovic-Gasic B., Simic D. and Knezevic-Vurkevic J., 2007, "Antimutagenic properties of Basil (Ocimum basilicum L.) in Salmonella typhimurium TA100" Food Technol.Biotechnol. Vol.45(2), 213-217.

9. Rubem Cesar Horn, Vera Maria Ferro Vargas. Antimutagenic activity of extracts of natural substances in the Salmonella/ microsome assay. Mutagenesis. 2003 March8 Vol.18, No2, 113118.

10. Anjana Bhatia, Saroj Arora et al. Evaluation of in vitro antimutagenic activity of "seabuckthorn" (Hippophae rhamnoides Linn.) in Ames assay. Journal of Chinese Clinical Medicine, 2007, 8; Vol.2,No8.

11. Wannee Rojanapo, Anong Tepsuwan, Antimutagenic and Mutagenic Potentials of Chinese Radish. Environmental Health Perspectives Supplements. 1993, Vol.101 (Suppl. 3): 247-252. 


\title{
ANTIMUTAGENIC ACTIVITY OF JUNIPERUS SIBIRICA BURGSD.
}

\author{
Byambasukh D. ${ }^{1}$, Odontuya G. ${ }^{2}$, Batkhuu $J .^{1}$ \\ ${ }^{I}$ Laboratory of Pharmacognosy, Department of Biochemistry and Bioorganic chemistry, \\ Faculty of Biology,NUM, batkhuu@biology.num.edu.mn \\ ${ }^{2}$ Natural Product Chemistry Laboratory, Institute of Chemistry and Chemical Technology, \\ MAS, odnoo_4091@yahoo.com
}

This study evaluated the antimutagenic and cytotoxic effects of some plants growing in Mongolia and plants were selected on the basis of their traditional use in various diseases. Over the past years numbers of cancer incidences are increasing in Mongolia. There are accounted several reasons, in particular the use of less guaranteed imported food, heavy air pollution, environmental contamination and low life quality of the population. Therefore, we attempted to search antimutagenic activity among plants from the Mongolian flora and possibility of their use for preventing and treating cancer cases. The study might promote the way to fight with cancer, if we can find antimutagenic active compounds from natural crude drugs, including medicinal plants.

We have examined the antimutagenic and cytotoxic effects of 20 samples, which prepared from different parts of 10 plants species. The antimutagenic and cytotoxic tests were performed as described by Ames. The bacteria used in the test are a strain of Salmonella typhimurium TA1537, and using 9-aminoacridine as direct mutagen.

From the 20 plant extracts studied, extracts of Achnatherum splendens Trin. (aerial parts), Cynoglossum divaricatum Steph. (roots, stems), Juniperus sibirica Burgsd. (leaf, stem) strongly inhibited mutagenicity of 9-aminoacridine and their inhibition activity was $49.7 \%, 41.5 \%$, $61.5 \%, 40 \%$ and $43 \%$ respectively. All plant extracts have not any cytotoxic effect on Salmonella typhimurium TA1537.

From the high active plants Juniperus sibirica Burgsd. (aerial parts) which was selected for further detailed study 3 pure active compounds as JS-1, JS-2 and JS-3 were isolated. The compound JS-3 showed the high (55\%) antimutagenic activity and its molecular structure was determined as cetyl alcohol or hexadecanol-1 according to its physical and chemical characteristics as well as ${ }^{1} \mathrm{H}-\mathrm{NMR}$ and ${ }^{13} \mathrm{C}-\mathrm{NMR}$ spectroscopy analysis.

We have revealed that the availability of plants possessing antimutagenic activity among the Mongolian flora. Consequently, it is needed further detailed study of active plants, isolation and identification of active pure compounds, as well as possible application of the active plant products in the medicinal practice. 